\title{
NOTES FOR THE GENEALOGICAL APPROACH TO THE TEACHING OF ENGINEERING
}

\author{
JAIME A. BENÍTEZ, LILIA E. APARICIO P \& MIGUEL A. ÁVILA A \\ Engineering Faculty, Universidad Distrital Francisco José de Caldas, Bogotá, Colombia
}

\begin{abstract}
The relationship between pedagogy and science is addressed in this article from the following question: ¿Do the contents of what we teach undergo any modification when it comes to being taught and does this modification create any novelty? The reflection in this article is oriented to the analysis of the relationship between pedagogy and science, with a genealogical vision of the emerging situations of the teaching-learning process since the 12th century.

KEYWORDS: Engineering, Education, Teaching
\end{abstract}

Received: Oct 06, 2020; Accepted: Oct 26, 2020; Published: Dec 01, 2020; Paper Id.: IJMPERDOCT202081

\section{INTRODUCTION}

Doing the genealogy of engineering education, leads us to reflect on the meticulousness and chances of knowledge without masks or appearances, evaluating with an attitude of self-criticism the prejudices and interests of the teacher in relation to knowledge and its teaching together with the attitude that the student can assume in front of the argument if all teaching is to teach the truth. The teacher and the student, as fundamental actors in the construction of pedagogical knowledge, must aspire to freedom of thought and a rational evaluation of the results of this process.

\section{IN THE CAROLINGIAN RENAISSANCE - TREASURING BOOKS}

Directing the attention to the events occurred before the 12th century, in the Carolingian Renaissance that marks a fundamental characteristic that is the treasure of books and writings not with the eagerness to know, to know and to be enriched, but with the spirit of keeping treasures; there science in this context is also a treasure. This inventory of writings acquires a very important value at the beginning of the 12th century because it is put into circulation as a legacy of contribution to the Renaissance of that century.

The appearance of monasteries oriented to form and prepare clerics; and of palace schools oriented to give knowledge to the sons of the nobility, in other words, teaching addressed to a closed elite, allows capturing a break in the teaching given where the outer schools of the monasteries were closed. This accumulation of books and manuscripts makes the truth be partially disclosed.

The Clergy devoted themselves to the task of writing great manuscripts, giving the angelic and divine satisfaction of assuring a place in heaven, "For them the essential thing is the application, the care, the time spent, and the fatigues suffered to write them. This work is a work of penance that will earn them a place in heaven [1]. 
The Middle Ages were precisely a time of crusades, conquests, wars, and mercantile exchanges in which cities emerged, majestic constructions created by the engineer of the time, or ingeniater, which means to create, a word assigned to those who devised and managed the ingenuity. Mathematics and physics are the areas of knowledge that strengthen the engineering profession, but this knowledge seems to belong to an elite. It is here, with the emergence of the cities, that the Intellectual makes his appearance, the books are exposed and the translators bring out the original Greek-Arabic ones who contribute the mathematics, astronomy, medicine, physics, logic and ethics and more than the matter, they contribute the method.

\section{THE INTELLECTUALS}

With the emergence of the Intellectual of the 12th century, the urban renaissance and the new economic, political and social structures, a new cultural space opens up with a relationship of knowledge and teaching that separates science from religion. The term Intellectual, designates those who have for office to think and to teach their thought. The intellectual is "a man whose job is to write or to teach or both at the same time, a man who professionally has an activity as a teacher and a sage, in short, an intellectual is a man who appears only with the cities" [2].

The emergence of Abelardo in the modernity of the 12th century, where the figure of Modern intellectual, who is credited with being the first teacher, who like many of today's teachers, continually tests himself and becomes a student himself to expand his knowledge, was a great dialectic who provided a method, giving great value to the word, his most valuable instrument, expression of reality. The students followed him in search of the understanding of reason and faith "one does not believe in what one does not understand and it is ridiculous to teach others what neither oneself nor one's listeners can grasp with intelligence" [3].

In the historical, social and cultural context of teaching, Abelardo is influenced by the Goliards; urban intellectuals antagonistic to the soldier who fights with weapons and emerges with a new intellectual style, for Abelardo the combat is then the ideas and passionate discussions with which it attracts students, here is recognized a special relationship between science and teaching, in which there is a close relationship between student and teacher in wanting to teach and wanting to learn.

At the end of the 12th century Chartres appears and, in his conception, the rational and humanistic spirit emerges that places man as the object and center of creation, a craftsman who transforms and creates with his instruments: his spirit and the books. The Chartres conception integrates man in the order of the world considering him as nature itself, for the reason he studies and understands nature. Honorio of Autun, the most famous of the 12th century popularizers, said: "Man's exile is ignorance; his homeland is science" [4].

Chartres considers that science should not be treasured but taught, but these craftsmen of the spirit that emerged in the urban development of the 12th century still need to organize themselves, to structure the form of teaching, it is here where the universities appear that are corporations of teachers and students with which a new and emerging relationship between pedagogy and science is established, they take advantage of all the discoveries of the audacious through books, which emerge as basic manuals for university teaching in the 13th century. University organization and formal education begin to be evident. 


\section{MIDDLE AGE-DECLINE}

The conception of the university teacher of the 13th century emerges with the political and economic power, with the decline of the Middle Ages, consequence of the wars, the political, social and economic structures are transformed and give way to the death of the intellectual of the Middle Ages and the humanist emerges. The urban classes are split in two, relegating the student of modest condition and the aristocrats integrate a group of privileged people who obtain resources from their intellectual work (lessons, exams.... ), tends to follow in a hereditary way in the chairs, bringing as consequence a reduction in the intellectual level of the university, "the teachers do not teach to be useful but, to be called gentlemen", the science is now an instrument of power, being understood as power the strength that gives the knowledge through which one obtains status and money, as well as in the engineering, the power that influenced for the emergence of its educational teaching, was the industrial development.

\section{MIDDLE AGE-DECLINE}

The conception of the university teacher of the 13th century emerges with the political and economic power, with the decline of the Middle Ages, consequence of the wars, the political, social and economic structures are transformed and give way to the death of the intellectual of the Middle Ages and the humanist emerges. The urban classes are split in two, relegating the student of modest condition and the aristocrats integrate a group of privileged people who obtain resources from their intellectual work (lessons, exams.... ), tends to follow in a hereditary way in the chairs, bringing as consequence a reduction in the intellectual level of the university, "the teachers do not teach to be useful but, to be called gentlemen", the science is now an instrument of power, being understood as power the strength that gives the knowledge through which one obtains status and money, as well as in the engineering, the power that influenced for the emergence of its educational teaching, was the industrial development.

The humanist of the Middle Ages divorced theory from practice and science from technique, disregarding manual labor. This humanist is a hermit in his knowledge, a solitary sage in his thoughts, breaks science and teaching; he is more literary than scientific and more fideistic than rationalist.

However, the learning of the engineer is configured from practice; with an unhumanistic vision, he trusts more in experience and in the observation of phenomena than in mathematical logic. His works were of simple design, although impressive for their size and the audacity of their execution, in general his works tended more to the functional than to the artistic and aesthetic.

The Construction Engineer arises from observations of nature. Thus, at the end of the 13th century, he develops applications of the knowledge of mathematics, physics, astronomy, rhetoric, geometry, mechanics, economy and art; and through these sciences he gives answers to the observation of phenomena.

Engineering education is aimed at pilgrims who learn to work the manual arts, the engineer of the time as an intellectual is possessed of this knowledge and teaches it, learning is used to meet basic needs, so it focuses on the handling of materials. 


\section{IN NEW HUMANISM AND THE UNIVERSITY}

Science in the 15th and 16th century impacts on technological and industrial advances, a new relationship emerges between pedagogy, science and knowledge, in which an important and dependent link is established between Teaching and Learning linked to the research university.

With the new humanism based on the investigative university and supported by the political will of the state to change, the investigative and free spirit is promoted in the student. It develops scientific thought and makes it possible to consider history as history. Human behavior frees man from his past and it is in this relationship of Pedagogy and Science that education is understood as self-education. The true student learns to develop from the known to the unknown and to approach the teacher, in this way, knowledge is produced through research which results in unavoidable modifications in the contents that are transmitted to the student.

The conception of the University of Berlin as a research university makes the university have a role in the production of science. It was characterized by the search for pure science and its academic organization in scientific conferences (Vorlesung), which give the student a systematic body of knowledge and the professor the opportunity to make known their scientific findings by making a confrontation of the contents of research. Humboldt said: "Freedom is essentially freedom of learning, of free access to sources and of academic neutrality in the face of different systems of values and beliefs"[5].

It is very important to note that the role of the student within a Socratic dialogue with the teacher gives him/her the opportunity to divulge the knowledge and scientific findings taken as their scientific production. The autonomous student learns and investigates with academic freedom that means full freedom from state power and its interests. This style of education gives the student an academic character from its ethical principles through intellectual self-education with an awareness of autonomy, freedom to act and think, which gives him unlimited responsibility.

It takes up again the significance of the direction that scientific knowledge acquires towards the totality of knowledge. It is said that "every scientific knowledge has to consider the totality of knowledge and truth. Whatever the concrete point or the specific discipline from which one starts, to think scientifically means to think with the spirit of totality" [6].

With the flourishing of inventions and scientific and technological advances, engineering has become a wellestablished and respectable profession, which has led to its diversification in response to the constant expansion of technological knowledge. Towards 1750, scientific contributions stand out, such as those of Galileo (astronomer and physicist) who formulated the scientific method as a means of acquiring knowledge; the discovery of the Law of the Fall of the Bodies, with Robert Boyle (chemist and physicist), the Law of Gases, with Robert Hooke (experimental scientist), the Theory of Elasticity and with Isaac Newton (scientist and mathematician), the development of mathematical calculation and the Law of Gravity. For the engineer, technology continues to be the reason and explanation of phenomena, the conception of science and knowledge. Science and knowledge show that every phenomenon has and is due to a cause. In the field of experience, causality prevails and makes freedom possible and phenomena have a cause, they are determined. 


\section{EMERGENCE OF ENGINEERING EDUCATION}

In 1747 the university education of engineering is established, at that time the first school of civil engineering "École des Ponts et Chausées" is created in France and there the idea of an engineering curriculum arises for the first time. It is here where an initial epistemological conception of engineering by the architect Thomas Tredgold appears which is: "The art of directing the great sources of energy of nature for the use and convenience of man". It seems then that he presents the engineer in a dominant position of the (thermal) technology placing this one in a superior level of the world. It is appreciated that engineering is almost the beginning of a new pedagogy, born from the experiment of teaching.

At the same time in Germany arises the structure of the University of Berlin that is clearly shaped with an objective and purpose in the context of a research university organization with autonomy and with a social and academic position of the university professor through a demanding professional exercise given by the breadth of scientific activity. The teacher takes direct responsibility for the contents he or she teaches. An institutional complex is formed where the professor is the master of a demanding practice of knowledge teaching. For Kant, man is what education makes him. In this perspective of progress, education plays a primordial role, it takes away the imagination; it is the belief of a certain form of progress that in Kant's words: "progress of the human race towards the best". A close and preponderant relationship arises in the formation of man and knowledge, that is, education of man for the production of knowledge, understanding man as the only rational creature on earth with natural dispositions directed toward the use of reason.

\section{ENGINEERING EDUCATION IN LATIN AMERICA}

Many ideological revolutions in Europe propitiate the rupture that would generate new conceptions of pedagogy and science, reaching Latin America and Colombia in particular. A constitutional reform is welcomed in our country influenced by the political model of Weimar, taking some principles and recommendations of the German pedagogical mission, based on freedom of expression and free knowledge without class differences. It allows women's access to university education, the grading scale for primary school teachers, the reorganization of the National University of Colombia, giving it institutional autonomy and creating the need for teacher training so the management of normal schools and the creation of the Escuela Normal Superior is resumed. Doctor José Francisco Socarras expressed in his report to the Ministry of Education in 1944: "The curriculum of the Escuela Normal Superior allowed to form scientists who were pedagogues who would master one or another of the sciences", a model of education for teachers was established and a relationship between pedagogy and science, product of the impulse given by the scientific vision of Germany and the humanistic vision of France.

With the fall of the liberal governments in Colombia, the abandonment of pedagogy is produced, which is relegated to structural changes and to the guidelines of education based on the principle of freedom, plurality and autonomy of the individual. The pedagogical institutions are taken over by the rulers of the moment, who lose their objectivity for what they were created; social sciences such as sociology, history, anthropology, among others, of equal importance, begin to detach themselves from pedagogy and adhere to the National University.

The generation of the violent ones begins, producing a break with the development discourse in which a new world order is proposed. The Western countries launch themselves into the race to generate wealth, for which they require capital to get closer to the industrialized countries. A new concept is present in the Western panorama and it is the planning concept of which technocracy exists. 


\section{AT PRESENT}

Within the framework of our university reality, within the context of pedagogy as autonomy, it can be said that "Currently it is widely accepted that the contents of the subjects taught in educational institutions are a pedagogical adaptation of the sciences that society has validated and considers necessary" [7]. This is understood to mean that society provides teachers with freedom and a space for the creation, acceptance, and transformation of content, without forgetting that the curriculum contains truths that interact with it indirectly, delimiting what is taught by popular traditions and the experiences of teachers themselves, which leads to modifications in the content.

The diverse socio-cultural origins of the students with pre-established concepts of science, most of which are biased, insufficient or mistaken in the rigor of their conceptualization and work, induce and even in a certain way force the teacher to assume attitudes of change or modification of those contents established during the development of the subject.

We could infer that the reality of the transformation of knowledge and the final result is a combination of the prepared content and what is built in the classroom. The teacher's own knowledge is the dominant one in what is to be transmitted to the student, even if he or she is intended to be redirected towards a dependence on those scientific contents. The academic agreement, understood as a business in the teaching task in which it is assumed by this own purpose of approaching the depth of science in the developed and updated without being framed in what is strictly governed by science.

The previous argument can be supported by the fact that "The selection made when defining the content of what is taught is intentional and responds to other rationalities that are not necessarily those of scientific production.” [8]. This phrase, expressed by the authors of the document Pedagogy and Epistemology, further strengthens the idea that the teacher, as a social being, participates in power relations and assumes an ideology, interests, beliefs and prejudices that make the objective scientific content fit his or her subjectivity.

Relocating to the context of the late 20th century, most engineering professors are highly specialized and have a great deal of knowledge in their field, few are trained in teaching. The teachers who are excellent teachers, or at least with good results in the exercise of teaching, have the natural gift of teaching or have acquired it in the exercise of their task as teachers. In addition, institutional guidelines for higher education usually impose very broad guidelines and flexible curricula on their teaching staff.

Thus, in the report that follows, it is suggested to direct the teaching of mathematics for engineers towards another path, that of the interpretation of results and not the traditional one of rigorous mathematics. Taking into account the technological advances and the tools that engineers have at their disposal for the development of the discipline, teachers should direct the teaching towards appreciation and not towards realization.

"A report on the mathematical training of engineers in Great Britain, generated a debate on the role that mathematics plays in the career. It is expressed that mathematics should be maintained as a fundamental part of the preparation of engineers. On the other hand, there is a conception that the mathematical requirement should be reduced. The accreditation board of engineering courses generated the debate regarding the level of mathematics needed by a profession where computers and information technology have revolutionized the way work is done. The problem is influenced by the way it is taught in high school. 
More than 50 years ago, the mathematics that engineers learned was driven by their practical work. But there have been great changes with the advent of computers, meaning that today engineers do very little structural engineering by hand. The mathematics they are taught must be related to appreciation and not to performance. The engineer must appreciate and understand what the computer does.

There must be a balance, it is possible that in previous programs there was a lot of incursion in mathematics during the formation of engineers, that mathematics should be induced by the demands of the subject to be taught.

Since the 1980's the changes in high school curricula and the freezing of programs and program content in universities with engineering faculties, has led to students getting lost in the context of the mathematics that must be learned by them.

In the new 1988 curriculum for secondary education, it reduces the contents of algebra and classical geometry, reinforced by a system of credits as a modular approach has meant that certain areas of knowledge have been forgotten and of little interest. There is a modality in which high levels of mathematics are required, the directors use external expert contractors in the engineering institutions while the engineers manipulate very little mathematical calculation.

The above is understood as a message that translates into the fact that what is important is not a high level of handling by itself but, a holistic awareness and an ability to recognize where mathematical work is needed.

But it is true that mathematics is necessary for the training of engineers because when there are few mathematical skills, there is difficulty in the analysis of planes or failure in the resolution of mathematical algorithms. Universities must recognize that the students in their engineering programs do not understand what they are trying to teach" [9].

With the over-modernity and technological developments of the 21 st century, it remains to be seen what effects the changes produced by the Internet and the introduction of the credit modality in university engineering training programs will have on the total context.

Engineering teachers should not start their teaching process towards students without first having a valid and reliable judgment about their training, because they would be a simple transmitter of specialized information and not a pedagogue and didactician of their knowledge. Student learning is built and transformed as new information is acquired that takes on meaning as it becomes part of their pre-existing cognitive structure. This meaningful learning is an interrelationship between the new knowledge and the existing ones, a relationship in which both are modified and interact with their teacher's knowledge.

\section{CONCLUSIONS}

In response to the initial question: ¿"Do the contents of what we teach undergo any modification when they are taught, and does this modification create any novelty?, we can state that yes, the contents of what is taught are modified when they are taught, and that they do create novelty in the classroom.

\section{REFERENCES}

1. Le Goff, J. (1996). Los Intelectuales en la Edad Media. Gediza: Barcelona.

2. Muller de Ceballos, I. (1995). Los orígenes de la universidad investigativa. Santafé de Bogotá: Centro de investigaciones de la Universidad Pedagógica Nacional (CIUP). 
3. Schelling, F, I. (1775-1854). Citado por Schelsky. Tomado de Los Origenes de la Universidad Investigativa.

4. Álvarez, G. A and others. Pedagogy and Epistemology. Group History of Pedagogical Practice. Ed. Magisterio. P. 295.

5. Ibiden. P.296.

6. New Civil Engineer International Magazine. August 2003. 